\title{
PALATALISATION IN DUBLIN IRISH, OR HOW TO SPEAK IRISH WITH A DUBLIN ACCENT
}

\author{
MARINA SNESAREVA
}

Lomonosov Moscow State University

\begin{abstract}
This paper focuses on palatalisation in Irish spoken by Dublin-based bilinguals with English as their first language. As opposed to previous researches in Irish phonetics and phonology, this study examines new speakers of Irish, whose speech was recorded in November 2014. All informants were born and raised in Dublin, lived either in the city or in the neighbouring counties and demonstrated sufficient fluency in Irish, i.e. had no problems with reading, could actively participate in conversation and give detailed answers without switching to English. Computer analysis of their data has shown that even though in traditional Irish dialects palatalisation is not position-bound, there is a correlation between palatalisation of a consonant and its neighbouring vowel quality in the speech of Dublin bilingualsdue to English influence andother factors.
\end{abstract}

Keywords: palatalisation, Irish Gaelic, Dublin, new speakers, phonetics, language contact

\section{Introduction}

Today Irish is recognised as the first official language of Ireland, and yet it has been in gradual decline since at least mid-19th century due to unfavourable social and extralinguistic circumstances (Ó Cuív 1951). At the same time it is regarded by the country's population as an integral part of their national identity (Hickey 2009: 69). English, while being the second official language of Ireland, is in fact the language of most Irish people, and for many of them it is the only one they speak. Even residents of the Gaeltacht ${ }^{1}$ are

1 This term is used to describe "those areas in Ireland where the Irish language is, or was until the recent past, the main spoken language of a substantial number of the local population. The Gaeltacht areas are defined by Government order and every successive government has 
fluent in English and can easily switch to it when the use of Irish is impossible or unwelcome.

Irish bilingualism is thus neither stable nor symmetrical - otherwise both languages would have been equally prestigious and had a similar number of speakers (Nelde 1998: 294). As a result, most Irish speakers can now easily switch to English, even within one sentence, which forms a favourable environment for language contact. And yet, while traditional Irish-speaking communities are steadily declining, the number of new speakers outside of the Gaeltacht is on the rise. The term 'new speaker' was introduced (O'Rourke and Walsh 2015) to move away from the negative connotations of the previous labels as well as to emphasise the importance of such speakers in language maintenance and revitalisation. In its broadest sense it can denote those who acquired the Irish language at school as an academic subject, i.e. the majority of Ireland's population. For the purpose of this paper, however, a more specific definition suggested by John Walsh and Bernadette O’Rourke is used, i.e. new speakers are "individuals who acquired the language outside of the home and who report that they use Irish with fluency, regularity and commitment" (O’Rourke and Walsh 2015: 64).

As most frequent speakers of Irish outside the education system are based outside the Gaeltacht and therefore are unlikely to be traditional native speakers, new speakers can play an important part in the future of the language. However, this role is sometimes undermined by those scholars who idealise the notion of the traditional dialect speaker, referring to the language of new speakers as 'post-traditional' or 'non-traditional' Irish (Ó Béarra 2007; Lenoach 2012; Ó Curnáin 2012).

\section{Palatalisation in Irish}

The consonant system of most Irish dialects consists of 31-33 phonemes, depending on status of velar nasals; in certain dialects additional sonorants are found $^{2}$ (see Table 1 ):

recognised the need for specific measures, structures and funding to ensure the maintenance of these communities" (Údarás na Gaeltachta).

2 See, for example, Ó Cuív (1944) and Ó Sé (2000) on the phonetic system of Munster Irish, Mhac an Fhailigh (1968) on the dialect of Mayo, de Bhaldraithe (1966) on Connemara and Lucas (1979) on Donegal Irish. 
Table 1. Irish consonant system

\begin{tabular}{|c|c|c|c|c|}
\hline & Bilabial & Alveolar & Velar & Glottal \\
\hline Nasals & $\mathrm{m} \mathrm{m}^{\prime}$ & n n’ & $\left(\mathrm{y} \eta^{\prime}\right)^{3}$ & \\
\hline Stops & p p' & $t^{\prime}$ & k k' & \\
\hline & b b' & d d' & g g' & \\
\hline Fricatives & $\mathrm{ff} \mathrm{f}^{\prime}$ & s s' & $\mathrm{X} X$, & h \\
\hline Liquids & v v' & $\begin{array}{l}1 \text { l', } \\
\text { r r, }\end{array}$ & y y' & \\
\hline
\end{tabular}

For most Irish consonants, the opposition of palatalised vs. non-palatalised is a binary one; however, in some dialects laterals and alveolar nasals have more than two variants (Hickey 2014). Different degrees of palatalisation can be explained by the history of Irish, which is a Goidelic language; it is believed that the ProtoGoidelic consonant system had a different opposition - that of strong vs. weak phonemes (Kalygin and Korolev 2006: 107). The opposition of strong vs. weak consonants was still present in Primitive Irish (Sommerfelt 1962: 349-359; Kalygin 2004), $/ \mathrm{y} /$ being the only possible exception as the corresponding strong phoneme $* / \mathrm{D} /$ is not reconstructed.

By the Old Irish period this distinction had almost been lost, and the consonant system was based on the opposition of palatalised vs. non-palatalised. However, alveolar nasals and liquids not only acquired the new opposition but also retained the old one (Thurneysen 1946; Quin 1975; Green 1997; Kalygin and Korolev 2006). In Middle Irish the opposition of palatalised vs. non-palatalised became binary for most consonants, with nasals and liquids being the only exception as they still had four different phonemes (Kalygin and Korolev 2006: 164). In standard Modern Irish the opposition of palatalised vs. non-palatalised is binary for all consonant phonemes, except /h/ (Green 1997; Hickey 2014). Most researchers agree that four types of sonorants have been preserved in none of the Irish dialects, while three types of laterals and alveolar nasals remain in Connacht and Donegal Irish only.

Thus, in Irish, palatalisation is systemic and performs phonological functions ${ }^{4}$. In English, on the other hand, it is strictly allophonic and can only occur before high front vowels (Guenther 1995; Bateman 2007; Pavlík 2009; Mielke 2015).

3 Even though velar nasals occur in the Irish language, not all scholars treat them as separate phonemes, pointing out that $[\mathrm{y}]$ and [y'] can only result from initial consonant mutation (Ir. deich ngabhar [y] 'ten goats' vs. deich ndoras [n] 'ten doors') or assimilation of alveolar nasals before velar stops (Ir. cúng 'narrow') (Ó Siadhail 1989: 82; Hickey 2014: 55). Other researchers, however, describe velar nasals as separate Irish phonemes (Green 1997: 41).

$4 \quad$ In Irish genitive singular and nominative plural of class 1 nouns such as cupán 'cup' are formed by palatalisation of their final consonant. De-palatalisation of the final consonant can also be used to form genitive singular (cf. máthair 'mother-NOM.SG', máthar 'motherGEN.SG'), though it happens less frequently. 
3. Research background: acoustic speech analysis

When determining whether a consonant is palatalised or not, surrounding vowels should be taken into account as well due to accommodation (Knyazev and Pozharitskaya 2012: 104-105). Namely, when a low back or mid-back vowel is pronounced next to a palatalised consonant, the second formant F2 of the vowel rises in the transition phase, i.e. right after the consonant or before it, which can be observed on the spectrogram. Quite the reverse, when a palatalised consonant occurs next to a front vowel, vowel F2 remains unchanged. Next to non-palatalised consonants the situation is different: here F2 of low back and mid-back vowels does not change and remains quite low, while F2 of front vowels drops in the transition phase.

Consequently, during acoustic analysis formants of neighbouring vowels are defined. Formant frequencies are measured both in the stationary phase (the middle segment where no noticeable changes of formants are observed) and in the transition phase (the segment right after the consonant or before it) to track their change. To illustrate that let us consider the initial consonant in beag 'little'. In this case, the consonant is followed by the back vowel [o:]:

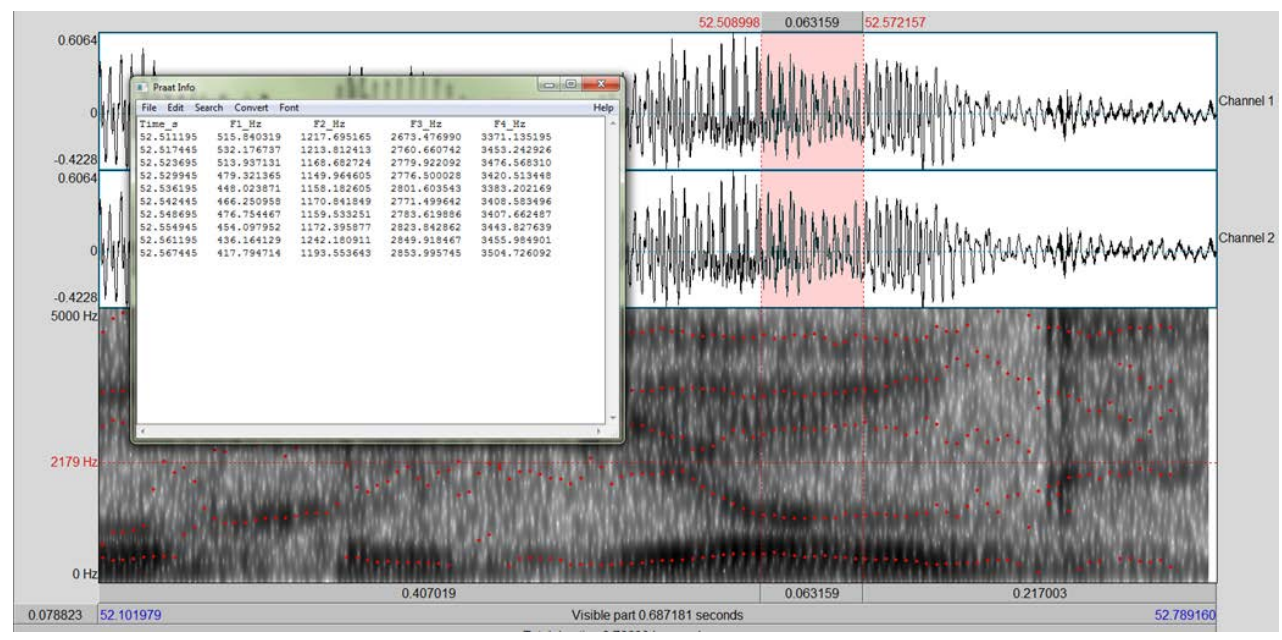

Figure 1. Formants of [o:] in beag 'little' measured in the stationary phase

In the stationary phase formant frequencies of the vowel are as follows. F1 $450-470 \mathrm{~Hz}, \mathrm{~F} 2-1160-1170 \mathrm{~Hz}, \mathrm{~F} 3-2770-2780 \mathrm{~Hz}$ (see Figure 1). In the transition phase next to the consonant they are different. F1 - 350-430 Hz, F2 1950-2000 Hz, F3 - 2690-2900 Hz (see Figure 2): 


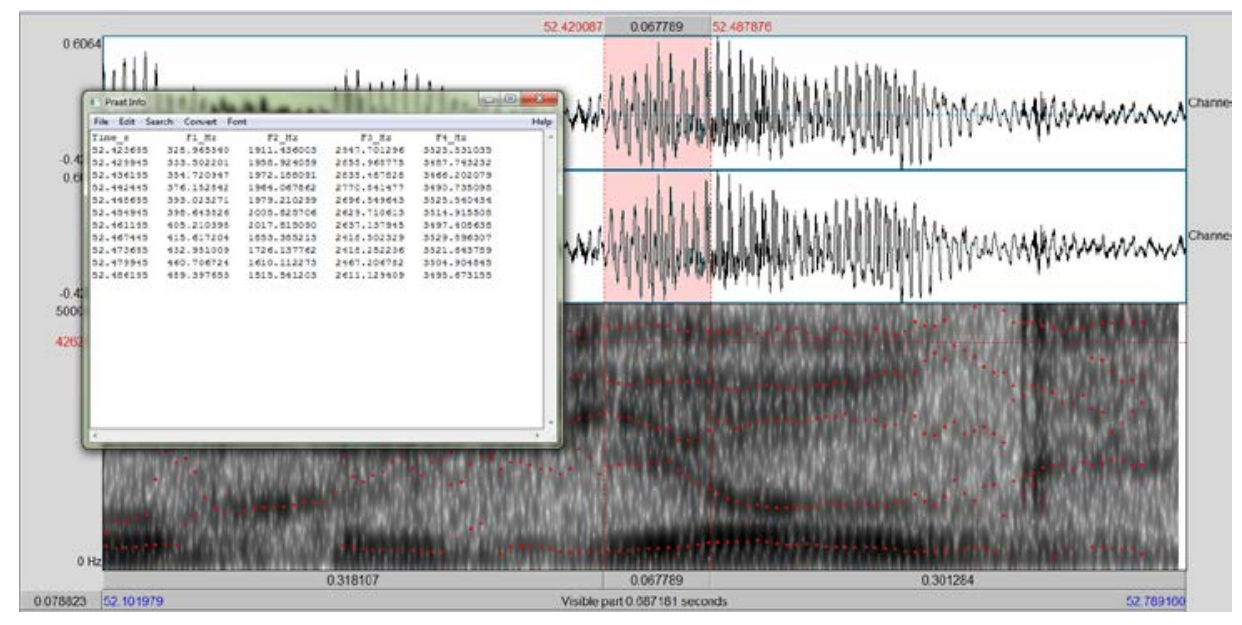

Figure 2. Formants of [o:] in beag 'little' measured in the transition phase

Praat can be used to draw a graph reflecting formant frequencies of the analysed vowel and their change (Figure 3), which shows a slight lowering of F1 in the transition phase (b is a stop) and a visible increase of F2 up to 2000 $\mathrm{Hz}$ as opposed to $1160-1170 \mathrm{~Hz}$ in the stationary phase. This signifies that the preceding consonant is palatalised:

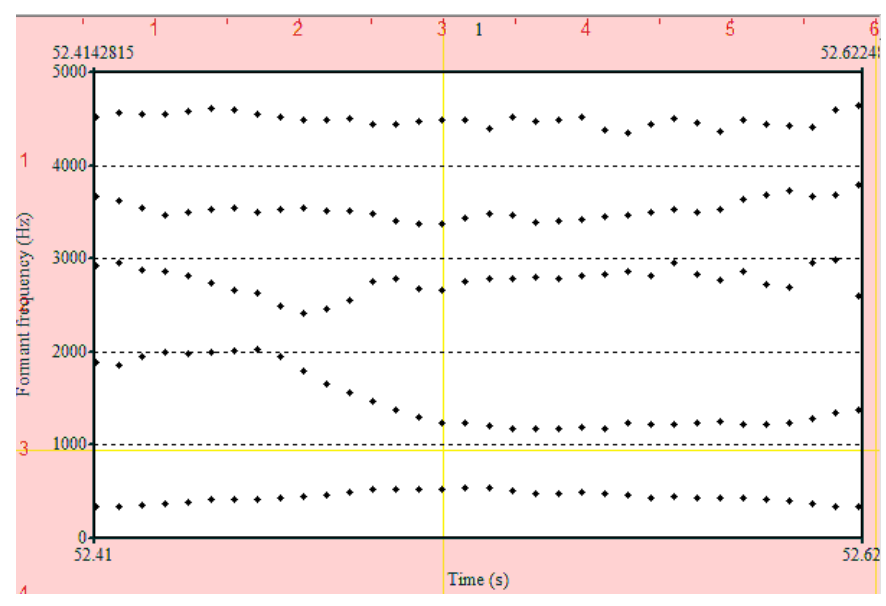

Figure 3. [o:] in beag 'little’: formant frequencies and their change

Indeed, when a non-palatalised [b] is pronounced in a similar context the picture is different. Thus, formant frequencies of [o] in bocht 'poor' in the stationary phase are as follows. F1 - 570-600 Hz, F2 - 880-910 Hz, F3 - 2940-2970 Hz (Figure 4): 


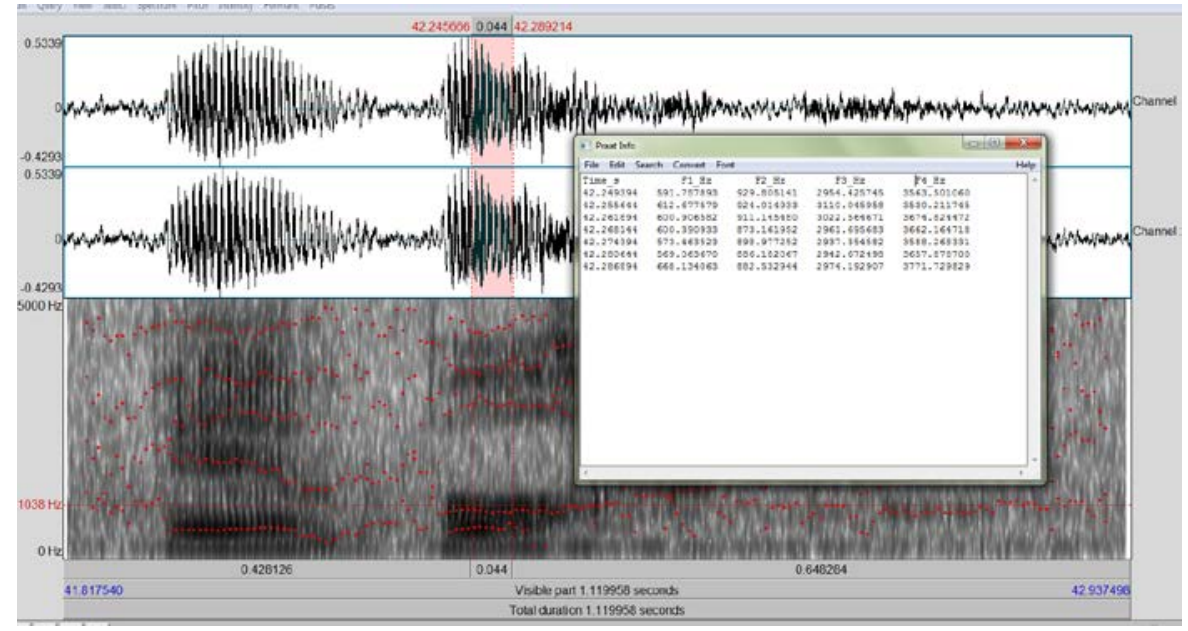

Figure 4. Formants of [o] in bocht 'poor' measured in the stationary phase

In the transition phase formant frequencies remain largely unchanged. F1 - 560570 Hz, F2 - 908-940 Hz, F3 - 3560-3615 Hz (see Figure 5):

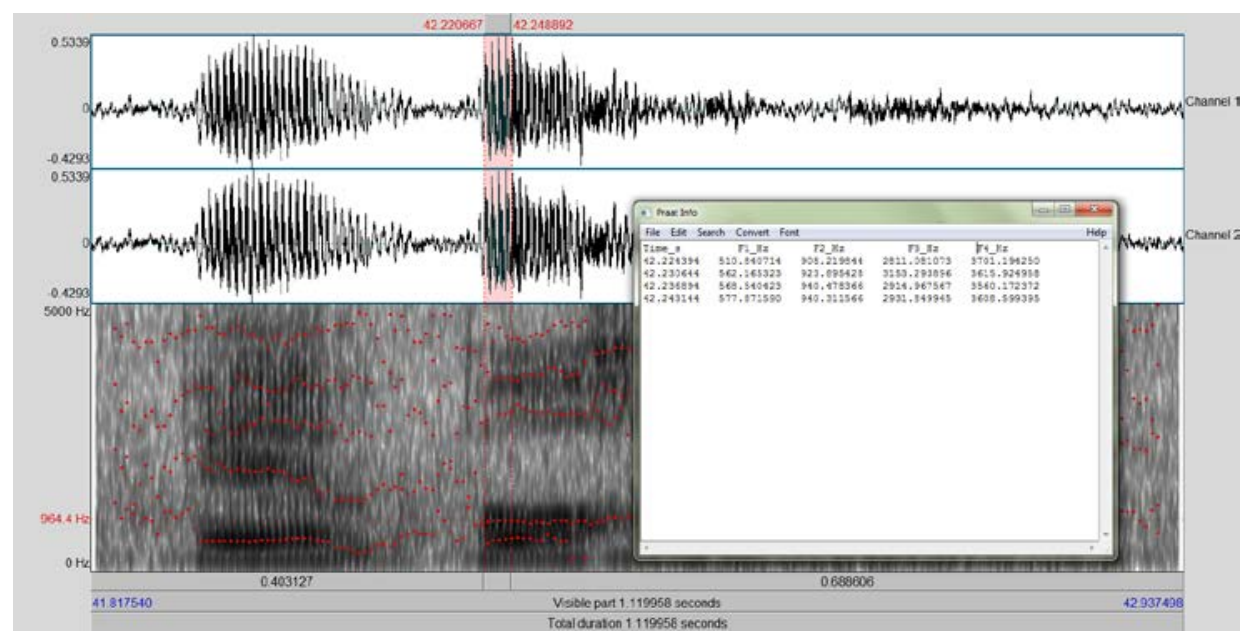

Figure 5. Formants of [o] in bocht 'poor' measured in the transition phase

As there is no significant change of vowel formants (see Figure 6) and the analysed vowel is a back one, the preceding consonant is not palatalised; otherwise there would be a visible rise of F2 next to the consonant: 


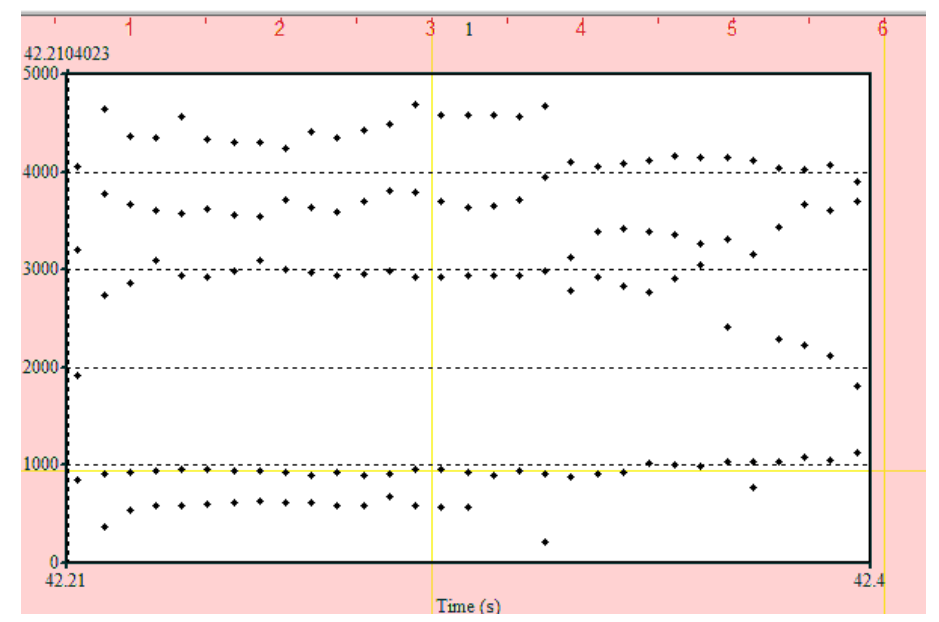

Figure 6. [o] in bocht 'poor': formant frequencies and their change

Quite the reverse, when analysing the quality of a consonant next to a front vowel, the absence of formant frequencies change means the consonant is palatalised, while next to a non-palatalised consonant F2 of the vowel is lower. To illustrate that, let us consider the initial consonant in daoine 'people'. In this case, the consonant is followed by the high front vowel:

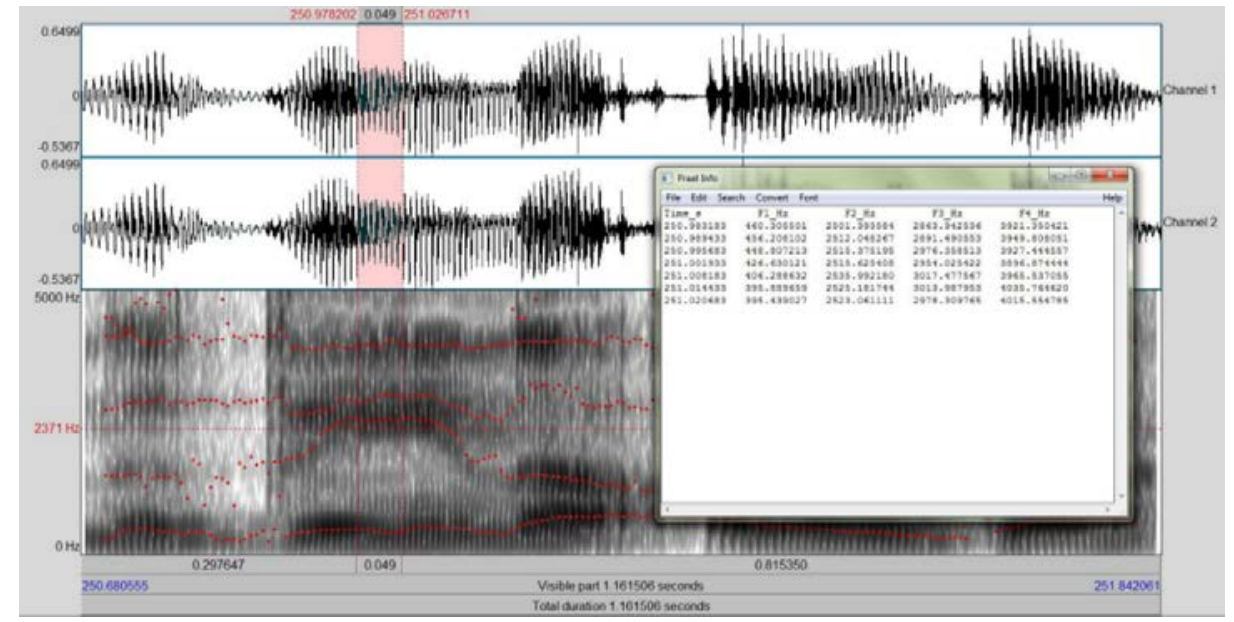

Figure 7. Formants of [i:] in daoine 'people' measured in the stationary phase

In this example vowel formants are as follows. F1 - 400-450 Hz, F2 - 2500-2530 Hz, F3 - 2900-3000 Hz in the stationary phase (see Figure 7), and F1 - 370-450 Hz, F2 - 1800-2400 Hz, F3 - 2640-2715 Hz after the initial consonant (Figure 8): 


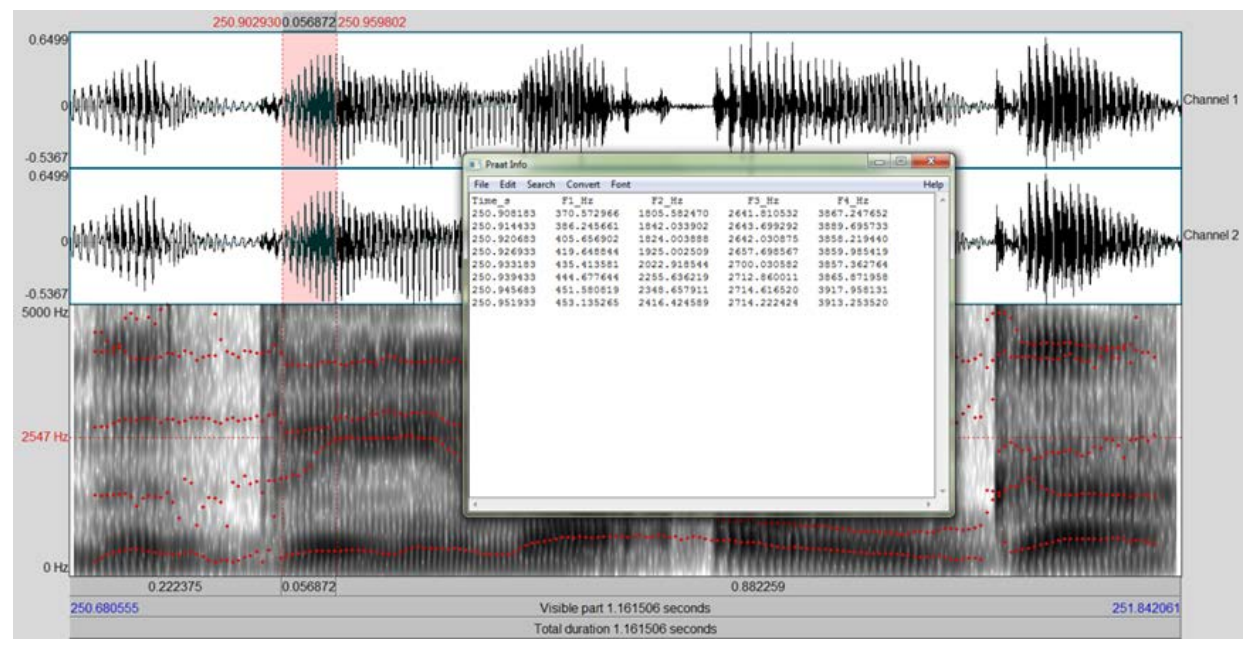

Figure 8. Formants of [i:] in daoine 'people' measured in the transition phase

If we draw a graph reflecting formant frequencies of the analysed vowel and their change (see Figure 9), it will show that F1 remains largely unchanged, the frequency of F2 is rather high (characteristic of a front vowel) but in the transition phase it drops to $1800 \mathrm{~Hz}$ as opposed to $2500 \mathrm{~Hz}$ in the stationary phase. Next to a palatalised consonant F2 of the front vowel should not change; consequently, in this example the consonant is not palatalised:

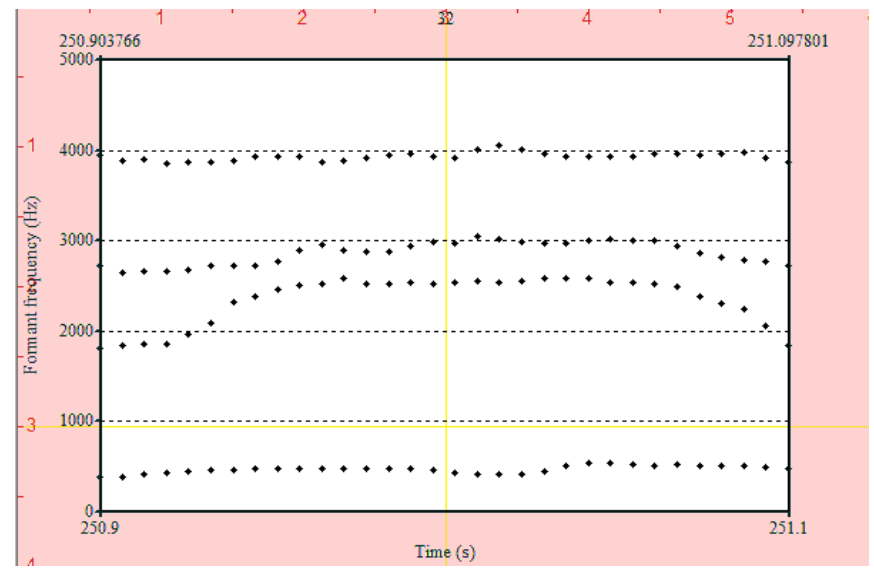

Figure 9. [i:] in daoine 'people’: formant frequencies and their change

When a palatalised consonant is pronounced in the same context the picture is different - the frequency of F2 remains high all the time, and the other formants do not change either (see, for example, Figure 10, where F2 of the high front vowel [i:] equals $2800-3100 \mathrm{~Hz}$ ): 


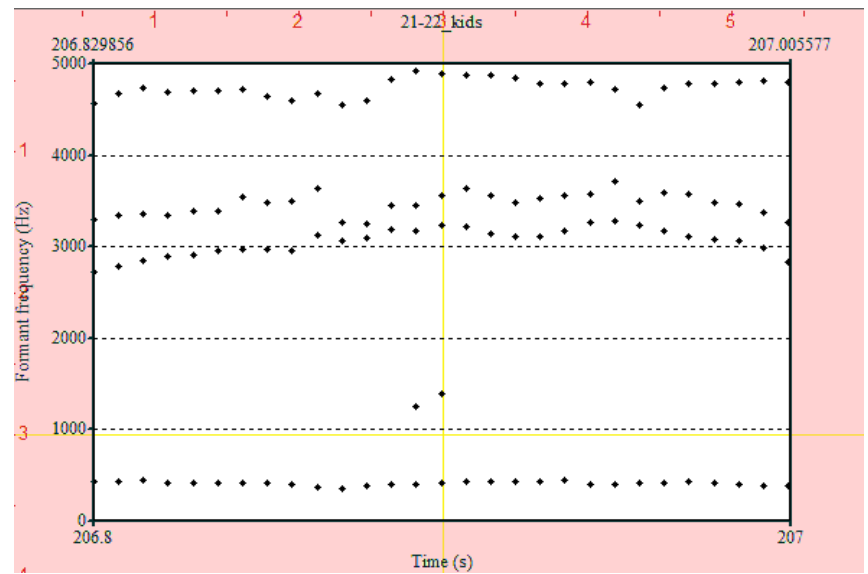

Figure 10. [i:] after [d'] in daoine 'people': formant frequencies and their change

As opposed to other consonants, sonorants have formant structure like vowels, therefore, to determine whether a consonant is palatalised or not, formant frequencies of both the neighbouring vowels and the sonorants themselves have to be measured. Palatalised sonorants have a somewhat higher F2 frequency than non-palatalised. As is the case with other consonants, palatalisation or its absence can be indicated by the change of the neighbouring vowel formants in the transition phase next to the consonant.

\section{Research background: interviews and informants}

In present-day Ireland, there are more bilingual Irish speakers with Irish as their second language than traditional dialect speakers. Many scholars emphasise the role of such speakers in language maintenance (McCloskey 2001). As the opposition of palatalised and non-palatalised consonants is phonological in Irish and strictly allophonic in English, it can present difficulties both for language learners and bilingual speakers whose first language is English (Ní Chiosáin and Padgett 2012). Even younger dialect speakers of Irish use palatalisation somewhat inconsistently, which is generally explained by English influence (Ó Curnáin 2012).

Indeed, mutual influence between contact languages has long been attested by scholars; it is also known as language interference, or "instances of deviation from the norms of either language which occur in the speech of bilinguals as a result of their familiarity with more than one language, i.e. as a result of language contact” (Weinreich 1953: 1). Linguistic factors facilitating language 
interference include typological similarity of contact languages, structural gaps, markedness of an element, equivalence of part of speech, and frequency of use in the source language (Gómez Rendón 2008).

In pronunciation, language interference and its extent are defined by a number of factors, including similarity of phonetic systems of the languages in contact (Flege 1995) and the age at which the speakers start learning their second language (Munro, Flege, MacKay 1996). Thus, it is believed that first language interference is more prominent in case of adult speakers (Ibid.). Furthermore, if a minority language comes into contact with another language, the latter is more likely to exert influence on the former (Paradis 2007; Gathercole and Thomas 2009; Grosjean 2010). This tendency applies in present-day Ireland, where the influence of the more prestigious and widespread English language on Irish occurs much more often than the opposite phenomenon, especially in urban speech (Tristram 2007). This was already attested in 1990s when Nancy Stenson discovered that phonological adaptation of English loanwords into Irish was only partial (Stenson 1993). The fact that such words tended to be preserved in their original form rather than assimilated in accordance with the Irish phonetic system was explained by widespread bilingualism in the country (Stenson 1993: 364).

The starting point for this research was thus a previously observed tendency to a different distribution of Irish palatalised and non-palatalised consonants in the speech of bilinguals as opposed to that found in the dialects. When discussing palatalisation, deviations can be divided into two types: palatalisation absence on the one hand, and use of a palatalised consonant instead of a non-palatalised on the other. In the first case a non-palatalised consonant is pronounced instead of a palatalised, for example, word-finally in cóip [p] 'copy', suimiúil [l] 'interesting' or word-initially in fear [f] 'man', bean [b] 'woman'. In the second case the speaker palatalises a consonant even though he/she was not expected to (word-initially in daoine [d'] 'people' and tús [t'] 'beginning', word-finally in mór [r'] 'big' etc.). Given constant language contact in Ireland and the absence of systemic palatalisation in English (the first language of informants), it was suggested that most deviations, if any, would be of the palatalisation absence type. While such pronunciations do not necessarily impede communication, in some instances they may result in ambiguity (for example, noun and case ambiguity in case of Irish class 1 nouns used without the definite article).

Another problem to consider was the status of Dublin Irish. While some scholars believe it to be "nothing more than an imitation of English" (Ó Béarra 2007: 262), there can be different processes at play. At the moment it may be impossible to give a definite answer to this question; however, if the speakers demonstrate tendencies in palatalisation use that cannot be explained by 
language contact, it can signify certain homogeneity of Dublin Irish and the possibility of its development into a full-fledged variant (new dialect) of the Irish language. Discovering such traits and tendencies is equally important sociolinguistically, as realising that Dublin Irish is not simply 'badly learnt language' but a variant in its own can influence the identity of Dublin bilinguals as full-fledged speakers of the Irish language, albeit not one of its traditional dialects. In its turn, a positive view of Dublin Irish may result in its more frequent use outside the Gaeltacht.

The data used include speech samples recorded during a field study in November 2014 when thirty-six Dublin bilinguals with English as their first and Irish as their second language were interviewed. Initially 50 informants were chosen based on email and phone communication. As Dublin is situated outside the Gaeltacht, this number seemed enough to arrive at justifiable conclusions. Indeed, the city is predominantly English-speaking, and the number of Irishspeaking citizens is extremely low, especially when one considers fluent speakers. Despite that Irish is an obligatory school subject in the Republic of Ireland, few reach the level of first language speakers and feel confident enough to communicate in Irish.

During face-to-face interviews, not all the bilinguals who had agreed to take part, appeared to have sufficient command of the Irish language. Therefore, only 36 informants were recorded for the research - 20 men and 16 women. All of them were born and raised in Dublin and at the moment of interview lived either in the city or in the neighbouring counties. If informants could not demonstrate sufficient fluency in Irish, i.e. had problems with reading, could not actively participate in conversation and give detailed answers without switching to English, their data were not considered. However, the questions used in the interview did not concern any specialised subjects and do not reflect the speakers' ability to use Irish in professional communication.

In addition to that, the speakers' data were not used if they had been born and raised in a different area (thus, one informant was born in Kerry and did not move to Dublin until early adulthood) or spoke a traditional Irish dialect they had deliberately learnt (another informant, being a Dublin native with a strong North-side accent in his English, spoke Connemara Irish to acquire which he had regularly travelled to the Gaeltacht).

Initially it was planned to record speech of young Dubliners, aged 17-18 (school graduation) to around 30, however, when remotely looking for informants, we discovered that a few Dublin-born and Dublin-raised speakers of older generations and school pupils wanted to participate in the research as well. As their level of competence satisfied the requirements, it was decided to include them as well. Therefore the age of informants varies from 12-13 to 64, yet most of them (24 speakers, or 67\%) are under 35 (see Figure 11): 


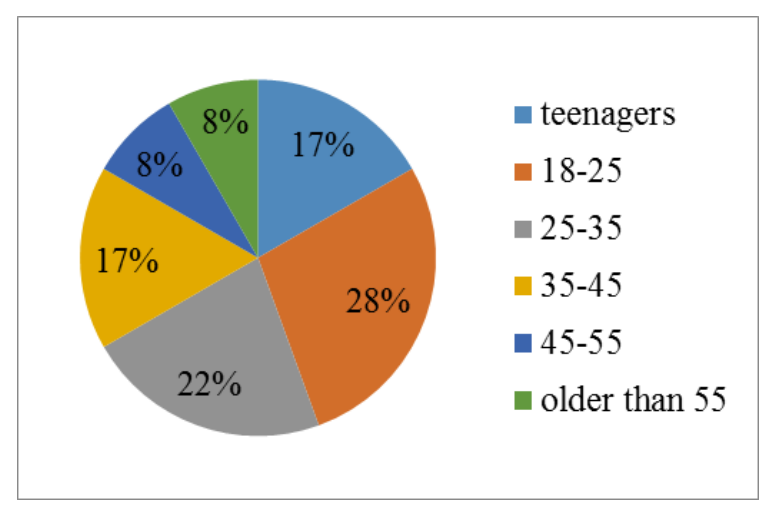

Figure 11. Dublin informants: age groups and percentage

The field study was needed to obtain recordings of both languages the informants spoke, Irish and English, with identical contexts for the consonants. The interview was divided into two parts and conducted in the language the researcher was recording. The Irish material was recorded at the very beginning to reduce possible interference of the speakers' first language, then the interviewer and the informant would switch into English and record the second part. To ensure reliability of the study, Irish consonants had to be recorded in different positions, especially in strong ones, where the contrast between palatalised and non-palatalised consonants is most prominent. As there is no opposition of palatalised and non-palatalised consonants in the English language, it was enough to get all English consonants in strong positions to define their characteristics (for example, word-initially before a stressed vowel). Therefore the main part of the interview consisted of words and wordcombinations in both Irish and English informants were to read aloud, which generated identical contexts, get every consonant in various positions ${ }^{5}$ and minimise influence of other factors, such as use of a similar sounding word or a different noun form ${ }^{6}$, on the speakers' pronunciation.

53 word combinations were selected for the Irish part of the interview (c.f. píosa páipéir 'a piece of paper', loch mór 'a big lake', lá báistí 'a rainy day’). The choice of material was based on the assumption that in traditional Irish dialects palatalisation presence/absence does not depend on vowel context (Ní

5 Consonants can occur in strong and weak positions and, as the contrast between them is more prominent in the former, deviations there are more significant. Therefore, only strong positions were analysed in this study. For Irish palatalised and non-palatalised consonants they are: word-initially before a stressed vowel, intervocalically after a stressed vowel and word-finally after a long or stressed vowel. The only exception here is $/ \mathrm{r} /$ for which the first position is substituted by a second element of a word-initial consonant cluster (Hickey 2014: 43).

$6 \quad$ As some Irish nouns form genitive singular and nominative plural by means of final consonant palatalisation, word-final palatalisation presence or absence in the recorded data due to the use of a nominative form in the context that requires genitive etc., had to be excluded. 
Chiosáin and Padgett 2012), i.e. that palatalisation is not position-bound. 31 word combination was used in the English part of the interview (c.f. tabby cat, love letter, seven geese). They were needed to get English consonants in strong positions to compare pronunciation of these sounds with their Irish counterparts.

All contexts underwent computer speech analysis to ensure that palatalisation or its absence was defined with the highest degree of certainty. Acoustic analysis was conducted using freely available software (Boersma and Weenink 2015) and followed by calculation of the number of deviations and their frequency.

\section{Deviations and their frequency}

When discussing palatalisation, deviations can be divided into two types: palatalisation absence on the one hand, and use of a palatalised consonant instead of a non-palatalised on the other. Their number varied but the average was quite low: 733 instances were singled out in total, corresponding to $11.9 \%$ of analysed consonants. This means that a competent Dublin bilingual with Irish as his/her second language pronounces $88 \%$ of consonants properly. In spontaneous communication, however, deviations are likely to be more frequent.

Palatalisation absence was by far the most frequent, accounting for $88.13 \%$ of all deviations (646 instances out of 733) and being observed in all positions. Wordinitially, it was absent in 182 examples out of 1044, i.e. in 17.43\% cases. Most deviations in this position concerned liquids, nasals and [f'] and occurred before low back vowels and, in a smaller number of cases, before [e:]. Intervocalically palatalisation was absent in 146 examples out of 720 , i.e. in $20.28 \%$ cases. In this position, deviations concerned not only liquids and nasals but also labial stops and labial fricatives, especially [p'], [f'] and [v']. They usually occurred after back and mid-back vowels [a], [a:], [o] and [o:]; however, in case of sonorants palatalisation was also absent after [i:] (c.f. tíre 'country-GEN.SG', dhílis 'dear') ${ }^{7}$.

Although palatalisation absence occurred in all positions, the majority of such deviations were encountered word-finally (318 instances out of 720, or 44.17\%). Here palatalisation was often absent in case of liquids, nasals and labial stops [p'] and [b'], while velar stops [g'] and [k'] had the least number of deviations. In this position, there seem to be a correlation between palatalisation absence and the neighbouring vowel length, as quite a number of deviations occurred after long vowels, irrespective of their frontness or backness. In addition to that, they were often found after back and mid-back vowels. Deviations could occur even if palatalisation absence potentially resulted in noun number and case ambiguity (c.f. cait 'cat- GEN.SG', cupáin 'cupGEN.SG', páipéir 'paper- GEN.SG', chloig 'clock- GEN.SG'). Potential ambiguity did

Some notes on the use of palatalised and non-palatalised sonorants in L2 Irish can also be found in (Snesareva 2014a). 
not seem to affect the speakers' verbal behaviour, even when a noun was used without the definite article and palatalisation of its final consonant (or its absence) was the only way to distinguish between different noun forms.

The second deviation type was less frequent and accounted for $11.87 \%$ of encountered deviations (87 cases). Even though their majority was expected to be of the palatalisation absence type, deviations of this type were also observed in the data. As opposed to palatalisation absence, they mostly occurred wordinitially. A comparatively low percent of such deviations can indicate instability of palatalisation in the Irish of new speakers due to English influence.

Word-initially, a palatalised consonant was pronounced instead of a nonpalatalised in 63 examples out of 1872, i.e. in 3.37\% cases only. Most deviations in this position concerned alveolar stops [t] and [d]. Intervocalically non-standard use was observed in 16 instances out of 864, i.e. in $1.85 \%$ cases, and only in one context ([d'] in bádóir 'boatman') a consonant was palatalised by several informants. As was the case word-initially, most mispronunciations concerned alveolar stops. As opposed to palatalisation absence, the number of second type deviations found word-finally was extremely low (8 instances, or $0.85 \%$ of all analysed consonants in this position); most deviations here were observed for alveolar [d] and [r].

Thus, irrespective of consonant position inside the word, the majority of second type deviations concerned voiced and voiceless alveolar stops. As a rule, palatalisation occurred before front vowels; this assumption does not exclude contexts like tús [tu:s] 'beginning' and buachaill [buəxəl'] 'boy' as the speakers who used [t'] and [b'] in these words pronounced then a fronted vowel rather than the back one, also as the first element of diphthong [uə] (see Figure 12):

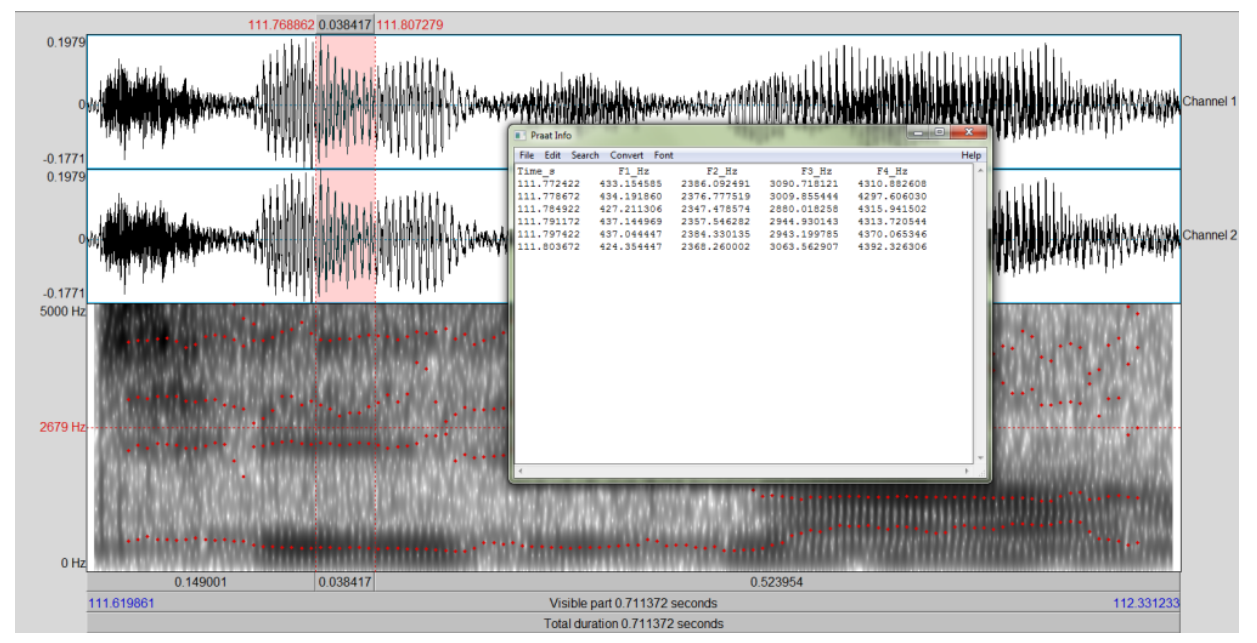

Figure 12. [t'] and a fronted vowel in tús 'start', formants in the stationary phase 


\section{Conclusion}

All informants spoke Irish confidently and could engage in a conversation without switching to English. The speakers had acquired the phonetic inventory of the language, including the differentiation between non-palatalised and palatalised consonants, even though the latter were not always pronounced consistently. At the same time their speech was not free from influence of their first language, English. Its direct phonetic interference was found in the following cases:

1. occasional pronunciation of approximant [r], especially and word-finally after a vowel;

2. pronunciation of affricates [d $]$ and $[\mathrm{t}]$ instead of alveolar [ $\left.\mathrm{d}^{\prime}\right]$ and [ $\left.\mathrm{t}^{\prime}\right]$ by some speakers; however, such use was not consistent and did not happen in all contexts.

Most deviations in the use of palatalised and non-palatalised consonants were of the palatalisation absence type. They were especially common next to back and mid-back vowels. Next to front vowels the situation was different; more often than not the speakers pronounced palatalised consonants in this position, even when palatalisation was not expected.

Previous research suggests that these tendencies also apply in weak positions (Snesareva 2014b). Consequently, even though in traditional Irish dialects palatalisation is not position-bound, in the speech of Dublin bilinguals there is a correlation between palatalisation of a consonant and its neighbouring vowel quality, possibly due to English influence. In English palatalisation occurs only before front vowels and is strictly allophonic, therefore bilingual speakers find it difficult to observe phonological oppositions in Irish. This explains why palatalised consonants are regularly pronounced next to front vowels, while in a different vowel context palatalisation is often absent. Indeed, it is much easier to produce palatalisation after a front vowel as organs of speech are positioned in a way that facilitates it. Quite the reverse, to palatalise a consonant after a back vowel, a visible change in the positioning of organs of speech is required. However, such consonant distribution was not encountered in all contexts; even those informants whose speech had deviations, in some cases used palatalisation properly (Snesareva 2016). This means that position-bound use of palatalisation is still a tendency rather than an entrenched feature of Dublin Irish.

Palatalisation and its absence in the Irish of new speakers was also affected by the consonant's place of articulation and the position of organs of speech that either facilitated or impeded palatalisation. Namely, the speakers tended to palatalise alveolar stops [d] and [t] in all contexts, which was manifested in less 
frequent palatalisation absence and a high number of second type deviations (the use of a palatalised consonant instead of a non-palatalised) for these consonants. As for palatalisation absence, it was more frequent in case of sonorants, bilabials and labiodentals. Therefore English influence cannot be considered the only reason behind non-traditional palatalisation use in Dublin Irish.

\section{REFERENCES}

Bateman, Nicoleta. 2007. A crosslinguistic investigation of palatalization. San Diego: University of California, Ph.D thesis.

de Bhaldraithe, Tomás. 1966. The Irish of Cois Fhairrge, Co. Galway: a phonetic study. Dublin: Dublin Institute for Advanced Studies.

Boersma, Paul and David Weenink. 2015. Praat: doing phonetics by computer [computer programme]. Available at: http://www.praat.org/ (accessed 29 May 2015).

Flege, James E. 1995. Second language speech learning: theory, findings, and problems. In W. Strange (ed.), Speech perception and linguistic experience, 233-272. Baltimore: York Press,

Gathercole, Virginia and Enlli Thomas. 2009. Bilingual first-language development: dominant language takeover, threatened minority language take-up. Bilingualism: language and cognition 12(2). 213-237.

Gómez Rendón, Jorge A. 2008. Typological and social constraints on language contact: Amerindian languages in contact with Spanish. Amsterdam: Universiteit van Amsterdam, Ph.D thesis.

Green, Antony D. 1997. The prosodic structure of Irish, Scots Gaelic, and Manx. Cornell University, Ph.D thesis.

Grosjean, Francois. 2010. Bilingual: life and reality. Cambridge, MA: Harvard University Press.

Guenther, Frank H. 1995. Speech sound acquisition, coarticulation, and rate effects in a neural network model of speech production. Psychological review 102(3). 594-621.

Hickey, Raymond. 2009. Language use and attitudes in Ireland: a preliminary evaluation of survey results. Sochtheangeolaíocht na Gaeilge: Léachtaí Cholm Cille 39. 62-89.

Hickey, Raymond. 2014. The sound structure of Modern Irish. Berlin: De Gruyter Mouton.

Kalygin, Viktor. 2004. Некоторые аспекты палатализации в кельтских и славянских языках [Some aspects of palatalisation in Celtic and Slavic languages]. In V. Vinogradov (ed.) Семиотика, лингвистика, поэтика: к столетию со дня рождения А.A. Реформатского [Semiotics, linguistics, poetics: celebrating 100th anniversary of A.A. Reformatsky], 109-116. Moscow: Slavic culture languages.

Kalygin, Viktor and Andrey Korolev. 2006. Введение в кельтскую филологию [Introduction to Celtic philology]. Moscow: KomKniga.

Knyazev, Sergey and Sofya Pozharitskaya. 2012. Современный русский язык: фонетика, орфоэпия, графика, орфография [Modern Russian: phonetics, orthoepy, script, spelling]. Moscow: Gaudeamus.

Lenoach, Ciarán. 2012. An Ghaeilge iarthraidisiúnta agus a dioscúrsa. In C. Lenoach, C. Ó Giollagáin and B. Ó Curnáin (eds.) An chonair chaoch: an mionteangachas sa dátheangachas, 19-109. Galway: Leabhar Breac.

Lucas, Leslie W. 1979. Grammar of Ros Goill Irish, Co. Donegal. Belfast: The Queen's University of Belfast. 
McCloskey, James. 2001. Guthanna in éag: an mairfidh an Ghaeilge beo? BÁC: Cois Life.

Mhac an Fhailigh, Éamonn. 1968. The Irish of Erris, Co. Mayo: a phonemic study. Dublin: Dublin Institute for Advanced Studies.

Mielke, Jeff. 2015. P-base: a database of sound patterns in 500+ languages [electronic resource]. Available at: http://aix1.uottawa.ca/ jmielke/pbase/index.html (accessed 11 December 2015).

Munro, Murray J., James E. Flege and Ian MacKay. 1996. The effects of age of second language learning on the production of English vowels. Applied psycholinguistics 17. 313-334.

Nelde, Peter H. 1998. Language conflict. In F. Coulmas (ed.) The handbook of sociolinguistics, 285-300. Oxford: Blackwell.

Ní Chiosáin, Máire and Jaye Padgett. 2012. An acoustic and perceptual study of Connemara Irish palatalization. Journal of the international phonetic association 42(2). 171-191.

Ó Béarra, Feargal. 2007. Late Modern Irish and the dynamics of language change. In H. Tristram (ed.) The Celtic languages in contact, 260-269. Potsdam: Potsdam University Press.

Ó Cuív, Brian. 1944. The Irish of West Muskerry, Co. Cork: a phonetic study. Dublin: Dublin Institute for Advanced Studies.

Ó Cuív, Brian. 1951. Irish dialects and Irish-speaking districts: three lectures. Dublin: Dublin Institute for Advanced Studies.

Ó Curnáin, Brian. 2012. An Ghaeilge iarthraidisiúnta agus an phragmataic chódmheasctha thiar agus theas. In C. Lenoach, C. Ó Giollagáin and B. Ó Curnáin (eds.) An chonair chaoch: an mionteangachas sa dátheangachas, 284-364. Galway: Leabhar Breac.

O’Rourke, Bernadette and John Walsh. 2015. New speakers of Irish: shifting boundaries across time and space. International journal of the sociology of language 231. 63-83.

Ó Sé, Diarmuid. 2000. Gaeilge Corca Dhuibhne. BÁC: Institiuid Teangeolaiochta Eireann.

Ó Siadhail, Mícheál. 1989. Modern Irish: grammatical structure and dialectal variation. Cambridge: Cambridge University Press.

Paradis, Michel. 2007. L1 attrition features predicted by a neurolinguistic theory of bilingualism. In B. Köpke, M.S. Schmid, M. Keijzer and S. Dostert (eds.) Language attrition: theoretical perspectives, 121-133. Amsterdam/Philadelphia: John Benjamins.

Pavlík, Radoslav. 2009. A typology of assimilations. SKASE Journal of theoretical linguistics 6(1). 2-26.

Quin, Ernest G. 1975. Old-Irish workbook. Dublin: Royal Irish Academy.

Snesareva, Marina. 2014a. Дистрибуция палатализованных сонорных в выученном ирландском [Distribution of palatalised sonorants in learned Irish], Филологические науки: вопросы теории и практики 10(3) [Philological sciences: issues of theory and practice 10(3)]. 170-173.

Snesareva, Marina. 2014b. Дублинцы и их ирландский: палатализация в условиях двуязычия [Dubliners and their Irish: palatalisation in a bilingual setting], Вестник Московского университета: серия 9, филология 6 [Journal of Moscow State University: series 9, philology 6]. 196-206.

Snesareva, Marina. 2016. Palatalization in Dublin Irish: the extent of phonetic interference. Procedia - social and behavioral sciences 236. 213-218.

Sommerfelt, Alf. 1962. Consonant quality in Celtic. In A. Sommerfelt (ed.) Diachronic and synchronic aspects of language, 349-364. The Hague: Mouton.

Stenson, Nancy. 1993. Variation in phonological assimilation of Irish loanwords. In E. Mushira and G. Iverson (eds.) Principles and prediction: the analysis of natural language: papers in honor of Gerald Sanders, 351-366. Amsterdam: John Benjamins. 
Thurneysen, Rudolf. 1946. A grammar of Old Irish. Dublin: Dublin Institute for Advanced Studies.

Tristram, Hildegard. 2007. On the 'Celticity' of Irish newspapers - a research report. In H.

Tristram (ed.) The Celtic languages in contact, 299-314. Potsdam: Potsdam University Press.

Údarás na Gaeltachta. Available at: http://www.udaras.ie/en/an-ghaeilge-an-ghaeltacht/anghaeltacht/ (accessed 1 June 2017).

Weinreich, Uriel. 1953. Languages in contact: findings and problems. The Hague: Mouton.

\section{List of figures}

Figure 1. Formants of [o:] in beag 'little' measured in the stationary phase

Figure 2. Formants of [o:] in beag 'little' measured

in the transition phase

Figure 3. [o:] in beag 'little': formant frequencies and their change

Figure 4. Formants of [o] in bocht 'poor' measured

in the stationary phase

Figure 5. Formants of [o] in bocht 'poor' measured

in the transition phase

Figure 6. [o] in bocht 'poor': formant frequencies and their change

Figure 7. Formants of [i:] in daoine 'people' measured

in the stationary phase

Figure 8. Formants of [i:] in daoine 'people' measured in the transition phase

Figure 9. [i:] in daoine 'people': formant frequencies and their change

Figure 10. [i:] after [d'] in daoine 'people': formant frequencies and their change

Figure 11. Dublin informants: age groups and percentage

Figure 12. [t'] and a fronted vowel in tús 'start', formants in the stationary phase

\section{List of tables}

Table 1. Irish consonant system 